\title{
Genres of Art History and \\ Rationales For and Against the Inclusion of Art History in Elementary School Curricula: \\ A Philosophical Study Addressing Clarification and Justification Questions Regarding Art History Education

\author{
Cheryl Williams
}

In the 1980s, three major art education forces in the United States laid the groundwork for the current resurgence of interest in incorporating art history into school curricula. Harkening back to ideas propounded in the 1960 s by Manual Barkan (1966), advocacy statements for the teaching of art history in America's schools were issued by the Getty Center for Education in the Arts (1985), the National Art Education Association (1986), and the National Endowment for the Arts (1988). Since these seminal publications, increasing attention has been directed toward consideration of the content and methodology of art history education; however, research that focuses on investigating the diversity of position taken concerning the desirability of teaching art history to children as part of their elementary schools experience has been largely neglected. Is it indeed desirable to include art history in elementary school curricula? Why? Why not? What are the philosophical platforms upon which both pro and con positions are built?

The "why's" and "why not's" of art history education need to be identified, analyzed, and articulated to guide practice in the field. For if art history is to be taught, then, to avoid aimless art history instruction, attention needs to be focused on the philosophical bases for and against its inclusion in school curricula. By examining the theoretical underpinnings that support its inclusion and weighing reasoning used to argue against such inclusion, it is also possible that opinions may be swayed away from currently prominent art education theory to conclude that art history should not be taught in America's elementary schools. An examination of justifications is called for to foster sound decisions regarding art history education.

Clarification of subject matter is also crucial for this endeavor. Concepts of "art history" and concepts of "art history in the context of elementary education" need to be researched and reported on to assist in determining what it is that educators should possibly teach.

Primarily philosophical in nature, my dissertation will identify and analyze a variety of types of art history, offer a range of rationales for and against the inclusion of art history in elementary school curricula, and provide recommendations concerning the desirability of teaching specified types of art history to children as part of their elementary school education. The study will focus on examining current (1980 onward) art education, art history, and 
general education literature. My research will add to the theoretical knowledge base upon which curricular decisions are made, teachers are trained, and educational practice is guided and, thereby, assist with strengthening art education practice in our schools. This paper is limited to an overview of that aspect of the study that provides a taxonomy of art history.

\section{Categorization and Identification of Types of Art History}

Certainly a broad array of types of art history exists. To provide insights regarding the variety of types of art history, I propose grouping them under the following five categories:

- TYPES OF ART HISTORY THAT FOCUS ON ART MAKER

- TYPES OF ART HISTORY THAT FOCUS ON ART OBJECT

- TYPES OF ART HISTORY THAT FOCUS ON CONTEXT OF CREATION

- TYPES OF ART HISTORY THAT FOCUS ON ART VIEWER

- TYPES OF ART HISTORY THAT HAVE MULTIPLE FOCUSES

The categorization scheme I offer clarifies what may be focused upon outside of an artwork itself: art maker, context of creation, and art viewer. Also, this framework provides a fifth category for those types of art history that overlap classifications.

Specific types of art history may be identified and placed within these categories. Biographical art history and what I label as "psych-based art history" are types of art history that focus on art maker. Formal art history and what I refer to as "content-based art history" are types that may be identified within the category that centers on art object. Social art history is a kind of art history that concentrates upon context of creation, and what I term as "perception-based art history" and "taste-based art history" are two genres of art history that focus on art viewer. Anthropologically-based art history and "the new art history" are types of art history that have multiple focuses. Certainly types and sub-types of art history exist other than those identified here; however, the above categorization and identification of types of art history provides a conceptual framework useful for defining and discussing a range of interpretations of "art history."

\section{Definition of a Variety of Types of Art History}

Within this paper, I define a selection of types of art history chiefly by presenting concrete examples of specific written histories of art and explaining how each is representative of a certain type of art history. To provide further clarity, I chose a theme for these examples: Leonardo da Vinci and his art serves as that connecting thread. Parrish (1987) introduced me to this idea and suggested three of the eleven examples I provide. The following six types of art history are represented as these most prevalently appear in art

Marilyn Zurmuehlen's Working Papers in Art Education 1993 
history literature: biographical art history, psych-based art history, formal art history, content-based art history, social art history, and the new art history. Additional types will be analyzed in my dissertation.

\section{Biographical Art History}

Giorgio Vasari's Lives of the Artists: Biographies of the Most Eminent Architects, Painters, and Sculptors of Italy (2 vols., 1550; expanded ed. in 3 vols., 1568/1946) is a classic example of biographical art history. It chronicles the lives of over 150 individual artists: its table of contents reads as a who's who listing of Italian artists from Cimabue to Michelangelo. As biographical art history equates the "history of art" to "the history of artists" and is sometimes accused of presenting "art as a testimonial to individual male genius" (Wallach, 1984, p. 31), it is especially fitting to depict it with Vasari's verbal sketch of Leonardo da Vinci.

Vasari begins by noting Leonardo's lineage and training and then proceeds to recount stories of Leonardo's life, attesting to the brilliance of Leonardo not only as a painter but also as a sculptor, musician, inventor, architect, engineer, and scientist. When Vasari discusses Leonardo's Last Supper, he provides an anecdotal account of the creation of this painting, as he does of other notable occurrences in the life of Leonardo.

\section{Psych-Based Art History}

Like biographical art history, that which I label as "psych-based art history" focuses on art maker. The basic difference between the two is that while the former addresses the artist's life history, psych-based art history explores the art maker's inner world and its manifestations. There are basically two variants of psych-based art history: psychological art history and psychoanalytical art history.

Psychological art history. Rudolf and Margot Wittkower (1963) paint psychological portraits of artists, specifically focusing on the image of "the alienated artist" in their book entitled Born Under Saturn; The Character and Conduct of Artists: A Documented History from Antiquity to the French Revolution. These authors discuss Leonardo in terms of his "aloofness." First, they analyze the writing of Leonardo himself, explaining how difficult it is to learn a Leonardo's emotions and personal thoughts from his extant notebooks: Leonardo's notebooks consist of 5300 pages of observations that, according to the Wittkowers, are "of an entirely objective nature" (p. 75). They point out this impersonality of Leonardo's writing to document his extremely aloof, and therefore eccentric, nature. The Wittkowers then draw upon Vasari's Lives of the Artists to further present and analyze Leonardo's personality.

Psychoanalytic art history. In Leonardo da Vinci: A Psychosexual Study of an Infantile Reminiscence, Sigmund Freud (1910/1916) seeks to 
further penetrate and explore the psyche of Leonardo and make connections between it and his artistic creations. Freud speculates on the meaning and significance of a childhood memory of Leonardo's and interprets Leonardo's paintings in light of it. He bases his analysis on a single passage from one of Leonardo's notebooks. Specifically, Freud suggests that Leonardo's paintings are an outgrowth of a vulture fantasy of Leonardo's childhood. In reference to Leonardo's Virgin and Child with Saint Anne (in the Louvre), Freud suggests that by portraying Mary and Mary's mother as similar in age, Leonardo symbolizes his own childhood that contained two mothers. Freud's conjectures regarding Leonardo and his art, however, have been refuted: Schapiro (1956) revealed that Freud based his work on an inaccurate translation of Leonardo's writing and that Freud's lack of research into the history of art led him to further misinterpret Leonardo's paintings. Nevertheless, Leonardo da Vinci: A Psychosexual Study of an infantile Reminiscence opened the door to a new pathway for art historical scholarship, and although contentious, this monograph by Freud serves as a premier example of psychoanalytic art history.

\section{Formal Art History}

Formal art history focuses on the artwork itself and, in particular, on the manner in which the artwork is constructed (Kleinbauer, 1971/1989). It analyzes the form or structure of the work of art and the subtleties of artistic technique, not the subject matter but rather the modes of representation. As the focus of investigation is on art object, rather than upon art maker, this type of art history varies categorically from biographical and psych-based art histories. There are at least two differing sub-types of formal art history: (a) what may be termed stylistic art history and (b) connoisseurship.

Stylistic art history. "Stylistic art history" refers to the analysis of the form of artworks for the purpose of increasing perception and understanding either of an individual artist's style or of the collective style of a group of artists. Leonardo: A Study in Chronology and Style by Carlo Pedretti (1973/1982) is an example of a stylistic art history that focuses on the work of a single artist: Pedretti articulates the style of Leonardo's drawings and paintings. For example, in one instance, he analyzes Leonardo's depiction of water, comparing Leonardo's use of line in his drawings of water around 1508-1510 to that in his anatomical drawings of the same time period.

In contrast, Principles of Art History: The Problem of the Development of Style in Later Art by Heinrich Wolfflin (1915/1950) is an example of a stylistic art history that focuses on collective style. Wolfflin sought to classify works of art by period styles, specifically the Renaissance and Baroque, based only on visual considerations. Throughout Principles of Art History, Wolfflin makes reference to Leonardo's Last Supper. However, these references are always relatively brief and are inserted purely to clarify and substantiate his classification of the classical style of the Renaissance.

Marilyn Zurmuehlen's Working Papers in Art Education 1993 
Connoisseurship. Like stylistic art history, connoisseurship studies the formal traits of an artwork. However, here the express purpose is to identify the maker, to verify it as an original, not a forgery, and to assess its quality or intrinsic value: it deals with attribution, authentication, and evaluation (Brown, 1979). The Salvator Mundi of Leonardo da Vinci by Joanne Snow-Smith (1982) is an exampie of connoisseurship that is highly informative regarding the process of making attributions. It is devoted exclusively to scrutinizing one Salvator Mundi (Savior of the World) painting and justifying the attribution of it to Leonardo. The book is a scholarly version of a whodunit thriller, as the reader is led on an exciting chase where supersleuthing efforts uncover a variety of clues that assist in the solving of a captivating mystery. Snow-Smith functions as the art detective: she pieces together documentary evidence and keenly analyzes and compares the visual elements of this painting with that of known works by Leonardo and Salvator Mundi paintings by others -- all done to convincingly solve the mystery of who "executed" this painting.

\section{Content-Based Art History}

What I term as "content-based art history" is similar to formal art history in that the art object is the center of attention for both; however, content-based art history focuses on the subject matter represented in the artwork and often the intrinsic meaning expressed, while formal art history focuses upon the manner of expression. "Content-based art history" is more often referred to in art historical literature as "iconography" and "iconology"; however, 1 have classified these a sub-types of content-based art history. Below, I identify three sub-types of content based art history based upon the writings of Panofsky (1955/1982).

Pre-Iconography. 1 propose that "pre-iconography" be considered a sub-type of content-based art history based on Panofsky's definition of "preiconographical description." Histories of art classified as such focus upon identifying the depiction of factual objects (e.g., persons, animals, concrete items), events, and expressional qualities in works of art. Identification of these "artistic motifs" is based on "practical experience," and the aim is to derive the primary or natural meaning of the content of artworks. An example within the theme of Leonardo and his art is Leonardo da Vinci: Drawings of Horses and Other Animals from the Royal Library at Windsor Castle (Leonardo, 1984).

Iconography. Iconography entails the decoding of stories and allegories represented in works of art by certain objects, specific artistic motifs, and combinations thereof. Identification of such is based on knowledge of literature and/or artistic tradition and is aimed at deducing secondary or conventional meanings of works of art. Because many of Leonardo's paintings and drawings depict specific themes, examples of iconographic writings regarding his art may readily be found. Jack Wasserman (1984), for example, decodes Leonardo's Last Supper primarily

Marilyn Zurmuehlen's Working Papers in Art Education 1993 
by exploring the conventional subject matter within the work: he goes beyond discussing this painting as a group of men eating together, to identify the work as a depiction of the Last Supper and to name each apostle, based on passages of the bible and consideration of artistic tradition. He thus addresses the conventional meaning of this painting.

Iconology. Iconology begins with the correct iconographical analysis and proceeds to attempt to decipher the "intrinsic meaning or content" of a work of art. Panofsky asserts that this deeper level of analysis aims to indicate values (of the artist and his or her society), the attitude of the artist's cultural milieu, and the underlying significance of the work of art through synthesizing, rather than analytic, process. An example of such is found in Frederick Hartt's (1969) interpretation of Leonardo's Last Supper. Like Wasserman, Hartt presents an assessment of the conventional meaning of Leonardo's Last Supper; however, unlike Wasserman, Hartt does not stop with this. He proceeds to interpret it as a conveyor of symbolic attitudes and values of Leonardo and his cultural milieu. Hartt presents it as representative of the High Renaissance "new and grander vision of ideal reality" (p. 401).

\section{Social Art History}

Up to this point, I have presented types of art history that focus on either art maker or art object. Social art history represents yet another focal point for art historical scholarship because it is context of creation which is studied. Generally, social art history focuses upon the collective context in which artworks were created and artists worked (Kleinbauer, 1971/1989). Societal factors that influenced and/or, some assert, determined the creation of artworks are searched for and studied.

Writing classified as social art history may generaily explore the relationship of art and society or may look more specifically at the relationship of art to specific social institutions or social, economic, political, religious, cultural, or intellectual factors (Kleinbauer \& Slavens, 1982). Thus, a variety of sub-types of social art history exists. Below, I present only the most prevalent form of social art history: correlational social art history (Kleinbauer \& Slavens, 1982).

Correlational social art history suggests generalized links or parallels between art and society. A prime example of such is The World of the Florentine Renaissance Artist: Projects and Patrons, Workshop and Art Market by Martin Wackernagel $(1938 / 1981)$. Neither Leonardo da Vinci nor the content or formal qualities of his art are specifically discussed in any length; instead, in stark contrast to the histories of art discussed previously, attention is shifted to the figures, societal forces, and events surrounding this artist and his work.

In the section of his book devoted to commissions, for instance, Wackernagel only briefly mentions Leonardo -- as merely one of many artists

Marilyn Zurmuehlen's Working Papers in Art Education 1993 
employed to create one of numerous Renaissance art commissions, specifically, a painting of the Battle of Anghiari. Wackernagel does indicate the basic subject matter of this painting but does not explore this in any depth, nor touch on the formal qualities of the work. Instead, he focuses on the function it was meant to serve: Wackernagel explains that Piero Soderini, conferred as constitutional head of state in 1502, commissioned this mural depicting scenes from Florentine military history during "the contemporary critical stage of the campaign against Pisa, ... to stand before the eyes of the Senate and people of Florence during all proceedings in the Council hall as a powerful exhortation to martial courage and energy" (p. 67).

\section{The New Art History}

One fairly recently developed type of art history is termed "the new art history." This is actually a generic name for several diverse challenges to the more traditional modes of art historical scholarship. It questions the subject matter, theoretical underpinnings, and theory structure of the discipline of art history (Rees \& Borzello, 1986). Up to this point, I have discussed various types of art history that predominantly address either art maker, art object, or context of creation. Also, I have identified other types of art history that focus on art viewer. A unique feature of the new art history is that it explores each or a combination of these focuses. It also analyzes the interrelationships of these categories and focuses upon theory that impacts all these areas. All this makes the new art history fit well under the heading of "TYPES OF ART HISTORY THAT HAVE MULTIPLE FOCUSES" -- and makes it indeed "new." Sub-types of the new art history may be identified, such as: the new social art history; semiotics-based art history; and feminist art history. Below, I present an example of feminist art history to illustrate the new art history and to clarify how it compares with other types of art history.

Feminist art history. Some feminist art historians seek to redress the marginalization of women artists by adding women artists and art objects created by women, as "the missing ingredient," to existing histories of art. Others, some in response to Linda Nochlin's (1971) notable call for "a feminist critique of the discipline of art history," seek a paradigm shift in the discipline of art history (Pollock, 1988/1990). Women, Art, and Society by Whitney Chadwick (1990) illustrates both of these approaches to feminist art history.

Related to the theme of Leonardo and his art, Chadwick devotes Chapter Two to presenting women artists of Renaissance Florence and the obstacles these women faced as artists -- and in Chapter Three, she shifts from the established canon of artistic periods to present "The Other Renaissance," asserting: "If women artists had a Renaissance, it surely took place in Bologna rather than Florence or Rome, and in the sixteenth and seventeenth centuries rather than the fifteenth" (p. 78). Women, Art, and Society is also illustrative of feminist art history in that in the preface and introduction to her text, Chadwick critiques art history's past discourse on 
women artists and calls for revisions in the content of, approach to, and structure of the discipline of art history.

\section{Implications}

In this paper, I have briefly defined a variety of types of art history, primarily through the use of examples. A more thorough explication of each will be provided in my dissertation and additional types will also be covered there. Each type of art history offers possible content for children's formal education. I believe that educators need to become more aware of the variety of conceptualizations of "art history" to assist them in making curricular decisions regarding art history education. If art history is to be included in school curricula, then knowledge of the range of types of art history is necessary for making judicious decisions concerning what form(s) that inclusion should take. However, the inclusion of any genre of art history in school curricula needs to be given thoughtful consideration.

A second major component of my dissertation will assist with this endeavor by identifying and analyzing a range of rationales for and against the inclusion of art history in elementary school curricula. Certainly the two strands of the study are intertwined, for determining the desirability of including art history in school curricula depends, to a very large part, on what type of art history is considered. Educators need to be well versed on the range of pro and con positions concerning such inclusion to wisely determine policy and practice. If any type of art history is to be included in an already packed curriculum and school year, then knowledge of the reasoning behind such inclusion would provide a defense for expenditures of time and resources on such and focus teaching efforts to more effectively achieve selected aims. And, if art history is not taught to elementary school children, then in light of recent advocacy for its inclusion in school curricula, educators need to be able to articulate justifications for omitting art history education.

\section{References}

Barkan, M. (1966). Curriculum problems in art education. In E. Mattil (Ed.), A seminar in art education for research and curriculum development (pp. 240-255). (U.S. Office of Education Cooperative Research Project No. V-002). University Park: Pennsylvania State University.

Brown, D. A. (1979). Berenson and connoisseurship of Italian painting: A handbook to the exhibition. Washington, DC: National Gallery of Art.

Chadwick, W. (1990). Women, art, and society. London: Thames \& Hudson.

Freud, S. (1916). Leonardo da Vinci: A psychosexual study of an infantile reminiscence (A. A. Brill, Trans.). New York: Moffat, Yard. (Original work published 1910)

\footnotetext{
Marilyn Zurmuehlen's Working Papers in Art Education 1993
} 
Getty Center for Education in the Arts. (1985). Beyond creating: The place for art in America's schools. Los Angeles: Author.

Hartt, F. (1969). History of Italian Renaissance art: Painting, sculpture, architecture. New York: Harry N. Abrams.

Kleinbauer, W. E. (1989). Modern perspectives in Western art history: An anthology of twentieth-century writings on the visual arts. Toronto: University of Toronto Press. (Original work published 1971)

Kleinbauer, W. E., \& Slavens, T. P. (1982). Research guide to the history of Western art. Chicago: American Library Association.

Leonardo da Vinci. (1984). Drawings of horses and other animals from the Royal Library at Windsor Castle (catalogue by C. Pedretti). New York: Harcourt Brace Jovanovich.

National Art Education Association. (1986). Quality art education: Goals tor schools, an interpretation. Reston, VA: Author.

National Endowment for the Arts. (1988). Toward civilization: A report on arts education. Washington, D.C.: U.S. Government Printing Office.

Nochlin, L. (1971). Why have there been no great women artists? In T. B. Hess \& E. C. Baker (Eds.), Art and Sexual Politics. London: Collier Macmillan.

Panofsky, E. (1982). Meaning in the visual arts. Chicago: University of Chicago Press. (Original work published 1955)

Parrish, D. C. (1987, Fall Semester). Lectures presented for the course Art History Methods at Purdue University, West Lafayette, IN.

Pedretti, C. (1982). Leonardo: A study in chronology and style.

New York: First Johnson Reprint. (Original work published 1973)

Pollock, G. (1990). Vision and difference: Femininity, feminism and the histories of art. London: Routledge. (Original work published 1988)

Rees, A. L., \& Borzello, F. (Eds.). (1986). The new art history. London: Camden Press.

Schapiro, M. (1956). Leonardo and Freud: An art-historical study. Journal of the History of Ideas, 17 (2), 147-178.

Snow-Smith, J. (1982). The Salvator Mundi of Leonardo da Vinci. Seattle: University of Washington. 
Vasari, G. (1946). Lives of the artists: Biographies of the most eminent architects, painters and sculptors of Italy (B. Burroughs, Ed.).

New York: Simon \& Schuster. (Original work published in 2 vols., 1550; expanded ed. in 3 vols., 1568)

Wackernagel, M. (1981). The world of the Florentine Renaissance artist: Projects and patrons, workshop and art market (A. Luchs, Trans.). Princeton, NJ: Princeton University Press. (Original work published 1938)

Wallach, A. (1984). Marxism and art history. In B. Oilman \& E. Vernoff (Eds.), The left academy: Marxist scholarship on American campuses (Vol. 2, pp. 25-53). New York: Praeger.

Wasserman, J. (1984). Leonardo da Vinci: Leonardo. New York: Harry N. Abrams.

Wittkower, R., \& Wittkower, M. (1963). Born under Saturn; The character and conduct of artists: A documented history from Antiquity to the French Revolution. New York: Random House.

Wolfflin, H. (1950). Principles of art history: The problem of the development of style in later art (M. D. Hottinger, Trans.). New York: Dover Publications. (Original work published 1915) 